http://www.epsj.journals.ekb.eg/

ISSN: 1110-5623 (Print) - 2090-0570 (Online)

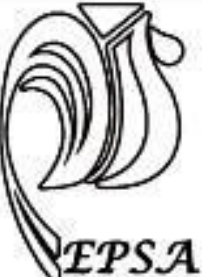

\title{
EFFECTS OF DIETARY TURMERIC AND FENUGREEK POWDER SUPPLEMENTATION ON PRODUCTIVE PERFORMANCE OF LOCAL LAYING HENS
}

\author{
H. M. M. Azouz
}

Anim. Prod. Res. Institute, Agric. Res. Center, Minis. of Agric. Dokki, Giza

Corresponding author: H. M.M. Azouz Email: azouz-h2010@ hotmail.com

Received: 05/02/2020 Accepted: 21/02/2020

ABSTRACT: This experiment was performed to study the effect of adding turmeric(TU) or fenugreek seeds (FE) and both of them in laying hen diets on productive performance. A total number of 90 hens of Sinai local strains, at 59-wks-old were used, weighed individually and allotted randomly into six experimental groups, with three equal replicates, five hens each. Hens had almost similar of initial average live body weights. The 6 treatments were: control treatment (T1) fed on basal diet. The second treatment (T2) was fed on basal diet with $0.1 \%$ turmeric powder. While third and fourth treatments (T3 and T4) supplemented with fenugreek seeds powder levels 0.1 or $0.2 \%$, respectively. Then, the fifth and sixth treatments (T5 and T6) were given turmeric at level $0.1 \%$ plus $0.1 \%$ or $0.2 \%$ fenugreek seeds, respectively. The results showed that hen group fed on a diet supplemented with $0.1 \% \mathrm{TU}+0.2 \% \mathrm{FE}$ (T6) achieved the best records of average egg numbers produced per hen and total egg number (60.3). Also, the same treatment attained higher laying rate and egg mass among experimental periods for overall period. Fenugreek seeds alone or with turmeric (T3, T4 and, T5) had positive effects on average egg weight, the heavier egg weight (53.7 g) for T4 during 71-74 wks of age compared with $50.6 \mathrm{~g}$ for the control treatment. Feed intake during the overall period was not significantly affected by studied feed additives. Meanwhile, T6 obtained the best FCR as compared with other treatments. Shell index, yolk index and albumin \% did not significantly affect by feed supplements. There was improvement in yolk \%, shell \%, shell thickness and Haugh units due to evaluated additives in hen layer diets. Hens fed on diet with $0.1 \% \mathrm{TU}+0.2 \% \mathrm{FE}$ (T6) recorded the highest net return and economic efficiency compared to other treatments. In conclusion, the results elucidate that adding turmeric, fenugreek or combination of them enhanced egg production, FCR and egg quality. Also, economic efficiency was improved by adding the mixture of the additives to elderly Sinai local hen diets at the late stage of productive age, $59-74$ weeks of age.

Key words: turmeric, fenugreek, laying hens performance, egg quality. 


\section{INTRODUCTION}

In the year 2050, the world will require 60$70 \%$ more animal products than currently required and produced (Makkar et al., 2015). This will lead to an increase in demand for table eggs. This, together with increased pressure for sustainable and safe food production from consumers, will make this task increasingly difficult. Optimum egg production is therefore particularly important to meet the future demands required. Production, however, can be easily compromised with inadequate nutrition, hen age, body condition, environmental stress, hen health. These factors need to be addressed, and therefore feed additives have been added to layer diets to combat the stressors that hens face during production.

Due to the negative light shed on synthetic feed additives such as antibiotics, researching natural alternatives to improve the production and egg quality of layer hens has become important. Natural feed additives such turmeric and fenugreek have the potential to reduce stress factors and boost production through improved growth and feed intake, as well as improved egg quality.

Curcumin powder stimulates bile production which will be required in emulsification of lipid (Seo et al., 2008). Supplementation of turmeric powder is expected to improve liver metabolism and maximize vitellogenin synthesis. Vitellogenin is transported through the circulation to the developing follicles and Phenolic compounds administration like curcumin may reduce gut inflammation, improve digestibility of nutrients and metabolism. Supplementation of turmeric powder up to $4 \%$ improved egg production performance of the old laying hen at a higher level with a lower cholesterol content (Rahardja et al., 2015).
Fenugreek seed is rich source of phytoestrogens and antioxidants (Mazur, et al., 1998; and Morton, et al., 1994). Saleh at al.( 2019) indicated that all productive performance was influenced by the fenugreek inclusion into the laying hens diets. In this regard, Moustafa (2006) found that fenugreek at the level of $0.05 \%$ improved feed conversion, but Criste et al. (2013) noticed that the use of fenugreek in layer diets in amounts of $1 \%$ and $2 \%$ had a negative influence on the egg production. The phytoestrogen content of fenugreek stimulates aromatase activity and promotes estradiol synthesis which in turn may have beneficial effect on secretary activity (Adil et al., 2015).In domestic fowls, ageing is associated with the reproductive failure. At the end of the laying period, egg production rate and shell quality were declined which resulted in substantial economic losses. This declining is connected with declining of all levels of the hypothalamic-pituitary gonadal axis (Johnson, 2000). In addition, several physiological changes coincide with the end of the laying period including reduction of circulating levels of oestrogens (Williams et al., 2005). Moreover, intestinal calcium absorption minimizes with age in hens ( $\mathrm{Gu}$ et al., 2013), which might be coincided with lower levels of estrogen receptor- $\alpha$ in both kidney and shell gland (Hansen et al., 2003).

Phytoestrogens are plant-derived compounds, which can act to mimic oestrogen and cause oestrogenic effects via binding to the estrogen receptor- $\alpha$ and estrogen receptor- $\beta$ (Yassein et al., 2015). The bioavailability of curcumin associated with phytogenics, the curcuminoids was eight-fold higher than that of the native curcuminoids, showing that this adjuvant 
turmeric, fenugreek, laying hens performance, egg quality.

can increase curcumin bioavailability (Her et al., 2018).

Therefore, the purpose of this research was to investigate the effect of different levels of turmeric, fenugreek and both together on layer hen production and egg quality.

MATERIALS AND METHODS:

This study was conducted at El-Serw Poultry Research Station, Animal Production Research Institute, Agriculture Research Center, Ministry of Agriculture, Egypt. It is started in 12/4/2018 and terminated in $1 / 8 / 2018$. Ninety Sinai laying hens at their $59^{\text {th }}$ to $74^{\text {th }}$ weeks of age were housed in laying pens in an open sided building. The birds were randomly assigned into six treatments of equal three replicates, each. At the onset of the experiment, birds were weighed and assigned to treatments based on body weight so that mean body weight was close for all treatments $(1620 \mathrm{~g} / \mathrm{hen})$. The birds were kept on deep litter, naturally ventilated laying house and were exposed to a daily photoperiod was of $16 \mathrm{hr}$.

\section{Layer's diet:}

Hens were provided with feed and water ad libitum and were fed standard layer diet contained $2730 \mathrm{kcal} / \mathrm{kg}$ diet and $16 \%$ crude protein. The diet was formulated according to the hen's requirement recommended by Ministerial Decree of the Ministry of Agriculture (1996). The chemical analysis of layer diet was calculated according to Feed Composition Tables for Animal and Poultry Feedstuffs used in Egypt (2001). Ingredients and chemical composition of the basal diet were shown in Table (1). All diets were isocaloric and isonitrogenous but it supplemented with turmeric and fenugreek powder where the experimental treatments were as follow:

T1: the basal diet (control group); T2: basal diet supplemented with $0.1 \%$ turmeric powder/ kg diet; T3: basal diet supplemented with $0.1 \%$ fenugreek powder; T4: basal diet supplemented with $0.2 \%$ fenugreek powder; T5: basal diet supplemented with $0.1 \%$ Turmeric powder $+0.1 \%$ fenugreek powder; T6: basal diet supplemented with $0.1 \%$ Turmeric $+0.2 \%$ Fenugreek powder.

\section{Productive parameters measured:}

Body weight of hens in each treatment was determined in the beginning of the experiment . Egg production \%, egg number/hen, egg weight, egg mass, feed consumption and feed conversion ratio through the experimental periods were recorded. In addition, three eggs per treatment were specialized to determine the external and internal egg quality.

\section{Economic efficiency:}

At the end of the study, economic efficiency for egg production was expressed as hen-production thought the study and calculated using the following equation:

Economic efficiency $(\%)=($ Net return LE/Total feed cost LE) $\times 100$.

\section{Statistical analysis:}

Data were statistically analyzed using General Linear Models Procedure of the SPSS (2008), differences between treatments were subjected to Duncan' $\mathrm{s}$ Multiple Range - test (Duncan, 1955).

The following model was used to study the effect of treatments on the parameters investigated as follows: $\mathrm{Yij}=\mu+\mathrm{Ti}+\mathrm{e}^{\mathrm{ij}}$ where:

Yij $=$ an observation, $\mu=$ overall mean, $\mathrm{Ti}$ $=$ effect of treatment $(\mathrm{i}=1 \ldots$ and 6$)$ and $\mathrm{e}^{\mathrm{ij}}$ $=$ Random error.

\section{RESULTS AND DISCUSSION \\ Egg production: \\ 1 - Egg Number/hen:}

Results in Table (2) showe the egg number / hen .Hens group fed diet supplemented with mixture of $0.1 \mathrm{TU}+0.2 \mathrm{FE} \%\left(\mathrm{~T}_{6}\right)$ 


\section{H. M. M. Azouz}

recorded the highest egg number (15.6) followed by the group given diet with 0.1 TU \% which record (15.4). The effects of supplementation were significant compared with the other treatments at the first period of the experiment (59-62 wks). However, hen group revealed an improvement of egg number / hen during the second period (63 - $66 \mathrm{wks})$, but was not significantly the supplemented the diet with blind of TU + FE (T6) recorded the high egg number followed by control group.

Studied feed supplements, solely or in mixtures in hen diets gave superiority in egg production number for all groups compared with control except $\mathrm{T} 3$ group, during the third period (67- 70 wks). Regarding the fourth period, hen fed the diet supplemented with $0.1 \mathrm{TU}+0.2 \mathrm{FE} \%$, T6 sharing $\mathrm{T}_{1}$ (control) scored the high egg number compared to the rest groups.

During the all experimental period (59-74 wks), the diet supplemented with turmeric plus fenugreek $\left(\mathrm{T}_{6}\right)$ had the greatest egg number followed by control group and diet with $0.1 \%$ TU (T2) which were 59.8, 59.2 and 58.3 , respectively.

The most remarkable result during the third period is that, hen group received diet with $0.1 \mathrm{TU}+0.2 \mathrm{FE} \%$ (T6) produced the highest number of egg produced than control group by about $4.8 \%$, also, this group had the first stage throughout the experimental periods constantly.

The present results are compatible with the results of Williams (2019) who reported that the use of fenugreek seeds derived products does not seem to affect the quantity of egg production. Similarly, Criste et al. (2013) observed that the use of fenugreek in layer diets in amounts of 1 and $2 \%$ had a negative influence on egg production. Also, Wahab et al.(2019) found that after ${ }^{2 n d}$ week, egg production was significantly decreased. While Alobaidy (2012) reported that fenugreek seeds had improvement in the reproductive performances of aged layer chicken.

Moreover, egg production performance of aged hens given diets with 1, 2 and $4 \%$ turmeric powder egg production $(\%$ hen day) was not significantly different (Rahardja et al., 2015). On the other hand, Kanagaraju et al. (2017) revealed that the supplementation of turmeric $(0.25 \%$ to $1.0 \%)$ in layer diets significantly increased hen day egg production.

\section{2- Laying Rate:}

Data in Table (2) demonstrated that there were significant differences between studied feed supplement forms on laying rate $\%$ during age from $59-62$ weeks of age. Hen groups diets supplemented with mixture of $0.1 \mathrm{TU}+0.2 \mathrm{FE} \%\left(\mathrm{~T}_{6}\right)$ recorded the highest level of laying rate followed by $\mathrm{T}_{2}$ which recorded 55.7 and $55 \%$, respectively.

The same trend of improving laying rate at age of 63 - 66 weeks, for hen received that diet containing mixture of TU + FE \% (T6) which was $56.2 \%$ followed by control which were $55 \%$ without significant difference.

Regarding age from 67 - 70 wks of age, also, hen group of T6 had the first seat of laying rate $(54.8 \%)$, the second seat for hen group of T5 sharing with T2 which record $52.9 \%$. Moreover, diet with mixture of feed additives T6 had the advanced site compared with the rest groups at the time of $71-74$ wks of experimental age.

With respect of, total experimental stage, the improvement between all treatment groups were not significant, while, treatment of $\mathrm{T} 6$ had the great laying production compared with other treatments. 
turmeric, fenugreek, laying hens performance, egg quality.

Generally, the distinguishing group among all the treatments in the number of eggs and laying rate $\%$ was the one that groups fed on diet with mixture of TU $0.1+\mathrm{FE}$ $0.2 \%$.There are conflicting results regarding the effect of adding fenugreek or turmeric to laying hens diet on the egg production rate. In this respect, Saleh et al. (2019) mentioned that hen day egg production was significantly increased by dietary supplementation of fenugreek. Awadein et al. (2010) reported increased egg production rate and related to fenugreek seeds dietary supplementation at 0.01 to $0.5 \%$ levels. Abaza (2007) obtained $2.23 \%$ increase in egg production at $0.5 \%$ fenugreek. Whereas Abdouli et al. (2014) reported that adding ground fenugreek seeds, there was a trend of reduction in laying rate (83.67 vs. $79.39 \%$ ).

An addition of 0.50 or $1.0 \%$ turmeric increased egg production significantly (Park et al., 2012). In contrast, Malekizadeh et al. (2011) found that the inclusion of turmeric root at the level of $2 \%$ in the diet did not affect significantly. Also, Riasi et al. (2012) found that adding turmeric at $0.5,1 \%, 1.5 \%$ and $2.0 \mathrm{~g} / \mathrm{kg}$ diet did not influence egg production of older laying hens.

\section{3 - Egg weight (g):}

Hens received control diet and diet with $0.1 \% \mathrm{FE}+0.1 \% \mathrm{TU}$ (T5) obtained high egg weight at the age of 59: 62 weeks, followed by hen group ingested diet plus $0.1 \%$ FE (T3). The later mentioned hen group T3 which fed on diet supplemented with $0.1 \% \mathrm{FE}$ recorded the second place for egg weight $(51.9 \mathrm{~g})$ after hen group received mixture of turmeric and fenugreek (T5) $52.8 \mathrm{~g}$ during age from 6366 weeks of age. Moreover, all treatments recorded higher egg weight comparing to control group except T6. At third period
(67-70) wks, turmeric plus fenugreek (T5) supplemented to hen diet scored higher weight followed by $\mathrm{T} 4$ which fed on diet with $0.2 \% \mathrm{FE}$.

During age of (71-74) weeks, hen fed on FE diets had the highest egg weight compared with the rest treatments and control.

Regarding turmeric supplemented diets $(0.1 \%)$ recorded higher egg weigh $(\mathrm{g})$ than control treatment during all experimental period except at period 59- 62 wks of age. In respect of fenugreek feed additive $(0.1$ and $0.2 \%$ ) diets had egg weight up than control during the same previous mentioned periods. Hen fed on T4 or T5 recorded 53.7 and $52.9 \mathrm{~g}$ while control recorded $50.6 \mathrm{~g}$, by other meaning recorded $6.13 \%$ higher than control egg weight during 71-74 wks of age.

Concerning, the supplementation the diet with mixture of turmeric and Fenugreek estimated higher egg weight production during all experimental period than other treatments and control.

It worthy to note that adding fenugreek solely or plus turmeric improved egg production weight.

The results of the present study are in line with researcher who demonstrated that egg weight increased in fenugreek seed extract fed groups (linear, $\mathrm{P}<0.05$ ) (park et al.; 2018). Another way, egg weight increased significantly after feeding turmeric at 0.50 or $1 \%$ as compared to the control diets (Rahardja et al., 2015). Similarly, addition of turmeric increased egg production and egg weight, but reduced the feed conversion ratio compared with the control group. (Gumus et al.; 2018)

\section{4 - Egg mass, g / hen:}

As shown in Table (3). Hens fed diets supplemented with additives were insignificantly affected on egg mass, g / hen during all experimental period. 


\section{H. M. M. Azouz}

However, hen group received mixture of turmeric $0.1 \%$ and Fenugreek $0.2 \%$ achieved the greater egg mass during all experimental period except (59-62) weeks of age. Furthermore turmeric group of T2 written down $20 \%$ greater than control for egg mass / hen during period (71-74) week of age (714.1 vs. 595.1g), respectively. While T6 hen group fed diet with the mixture written down the second place next to the T2 turmeric group which recorded $686.2 \mathrm{~g}$ in the same period.

On the other hand, adding turmeric TU $0.1 \%$ and fenugreek $0.2 \%$ together to hen diet at late age of egg production resulted in greater improvement in egg mass comparing with adding every one of them solely to the diet and hens received the control.

In agreement with the current findings, Safaa (2007) reported that fenugreek did not have a significant effect on egg production, egg weight and egg mass. In contrast, with Saleh et al. (2019) indicated that hen day egg production and egg mass were significantly increased by dietary supplementation of fenugreek.

Park et al. (2012) reported that supplementation of turmeric at $0.1,0.25$ and $1.0 \%$ did not influence of egg on old leghorn laying hens. Also, the same level of turmeric powder (1\%) had no effect on egg mass production

(Emadi and Kermanshahi, 2007).

\section{Laying performance:}

\section{1 - Feed intake:}

Results concerning feed intake are presented in Table (4). The results indicated that there are insignificant effects of dietary supplementation on feed consumption during overall experimental period except during period 63-66, and 6770 weeks of age, where, they were differ significantly. During the period 59-62 weeks of age, all treatments consumed lower feed than control treatment except T6 had the highest amount of intake comparing with those fed the control diet (106.1 vs. $104.8 \mathrm{~g}$ ).

Moreover, at the second period of experiment (63-66 weeks), hen groups fed diets with additives consumed less amount comparing with control group, especially T5 and T4 ingested the lowest amount of feed intake than control, which were 98.4, 100.2 and $108.4 \mathrm{~g}$ respectively. However, At the third period (67-70 wks.) hen groups fed on T5 and T4 ingested more than other groups, their consumption amounts were (115.5, and 113.1g) comparing with control (108.2 g).

Over all experiment al period (59-74) weeks of age, hen group received diet with mixture of turmeric and fenugreek T5 obtained lower feed consumption during the overall period compared to the rest of groups, followed by hen group fed on T4 diet sharing with hen group of T3, while control group had greater feed intake.

The results are compatible with the results of Moustafa (2006) indicated that fenugreek at levels $0.05,0.1$ and $0.15 \%$ did not affect feed consumption by $\mathrm{Hy}-$ Line White laying hens during 40-59 weeks of age. Abdalla et al. (2011) indicated that there was no effect of supplemented fenugreek at $1 \%$ level on feed consumption for Gimmizah laying hens.

Feed intake in the birds fed diets containing from 0.50 up to $2.0 \%$ turmeric powder did not differ significantly (Radwan et al., 2008; Laganá et al., 2011; and Rahardja et al., 2015). Feed consumption was not changed by the dietary treatments, suggesting that dietary addition of turmeric powder did not affect palatability( Park et al., 2012). 
turmeric, fenugreek, laying hens performance, egg quality.

\section{2- Feed conversion ratio:}

Data in Table (4) shown that hen group fed on control diet attained the lower (FCR) 3.7, followed by hen group received diet plus mixture of additives (T5) which was 3.8 , at the first period (59-62 weeks of age).

It is noticed that, during the second period (63-66 wks.) an improvement was occurred on feed conversion ratio values in all treatments except the control, the better FCR (3.6) was recorded for hens given T6 diet.

Also, that, previously mentioned hens group given T6 diet recorded the best FCR (3.9) during the third period of experiment (67-70 wks) and during the overall experimental period (59-74 wks. of age). While, hens group ingested diet with turmeric obtained the lower FCR value during the period of 71-74 weeks of age.

Generally, the diets supplemented with turmeric, fenugreek or mixture of them lead to improvement in FCR (g Feed / g egg) especially for T6 hen group fed on diet which contain $(0.1 \%$ TU plus $0.2 \mathrm{FE}$ $\%)$. Adding the two additives together for hen diet make efficient for FCR values as a results for their effects put together in the diet, than for one thing.

Adding fenugreek to turmeric rise its activity by increasing turmeric bioavailability in the body especial in the liver.

In addition, the results are consistent with those of Omri et al. (2017) who reported that fenugreek supplemented diet was associated with feed conversion ratio slightly higher than that of the control. Also, Abdouli et al. (2014) found that a trend of increase in FCR from 1.93 to 2.17, when ground fenugreek seeds were supplemented in layer hen diets. While, Park et al. (2018) revealed that the inclusion of fenugreek seeds in the laying hen diet did not significantly affect feed intake, or feed conversion between treatments.

There is a discrepancy regarding the addition of turmeric to laying hens feed, Radwan et al. (2008) observed that feed conversion ratio in the layers fed turmeric at 0.50 or $1 \%$ was improved. While, Laganá et al.(2011) reported that feed conversion ratio and average daily feed intake were not affected by $0.50 \%$ turmeric powder.

\section{Egg quality:}

The effect of dietary supplementation by turmeric, fenugreek and mixture of them on egg quality of laying hen during later period of egg production is shown in Table (5).

The data indicated that no significant differences were observed due to additives in shell index, shell weight $\%$, shell thickness and yolk index during the experimental period. While, there were statistical changes of yolk weight \%, albumin weights $\%$ and the Haugh units at the overall experimental period.

The data regarding shell parameters declared that control group recorded higher shell index followed by group of T6, while hen group had $0.1 \%$ FE scored greater shell weight $\%$ redirected by $\mathrm{T} 5$ group ( 13.6 and 13.4 respectively) comparing with other treatments.

The third parameter of shell illustrated T6 hen group fed $0.1 \% \mathrm{TU}+0.2 \% \mathrm{FE}$ written down the higher value enrolled by birds group fed diet with $0.1 \%$ TU sharing birds received $0.2 \%$ FE. Hen group fed basal diet reviewed the first seat of shell index (0.27) compared to the rest groups. Haugh units of birds fed on diet with fenugreek or the mixture with turmeric improved significantly, where group of T5 had the highest units (93.18) followed by group of T6 (91.36) in comparison the 


\section{H. M. M. Azouz}

other groups. Also, hen group fed on diet with $0.1 \mathrm{TU}$ (T2) improved significantly for yolk weight percentage. In respect to, albumin \%, hen group fed the basal diet achieved the higher albumin $\%$ followed by hen group of T6 diet.

The results are supported by some other researchers' studies as follows:

Shell parameters: Hassan et al. (2003) concluded that there was no significant effect of the germinated fenugreek on egg quality. Also, Omri et al. (2017) showed that shell weights were not affected by diet with fenugreek. As well, Wahab et al. (2019) noticed that egg quality traits including egg shell weight, egg shell thickness, were not affected by supplementation of fenugreek seeds. Furthermore, Elangovan et al. (2011) mentioned that the egg quality parameters viz. shape index, shell weight and shell thickness remained similar in all the dietary treatments.

With respect to turmeric supplementation, Curvelo et al. (2011) reported that feeding different levels $(0.50,1.0,1.5$ and $2.0 \mathrm{~g} / \mathrm{kg}$ turmeric powder of feed) to the laying hens had non-significant effect on specific gravity, egg shell thickness, egg shell weight and egg shell weight to egg weight ratio. No differences in feed intakes, egg and eggshell qualities were observed between the treatments, but Roche color fan number (yolk color) in group fed diet with $0.5 \%$ turmeric powder was significantly higher than in control ( $\mathrm{P}<0.05)$ (Park et al., 2012).

Yolk parameters: The current results of improving yolk weight by adding fenugreek to layer hen diet as detected by Panaite et al. (2015) who reported that the yolk weight increased for the $2 \%$ fenugreek concentration group, while for the control group. Also, Williams (2019) found that fenugreek seeds derived products fed layers displayed an increase in yolk height and color. As well, Saleh et al. (2019) confirmed that Shell thickness and yolk weight and color were improved by supplementation with fenugreek seeds. Turmeric powder administration and ration quality did not affect yolk index, egg shell index and Haugh unit (Saraswati et al., 2013)

Reported that supplementation of turmeric powder had no significant effect on external and internal egg qualities in laying hens as compared to control groups (Rajesh et al., 2018 ).

Haugh units and albumen weight: The indicator of albumin quality of (Haugh unit) was significantly increased with $0.5 \%$ fenugreek treatment Awadein et al. (2010). As well dietary turmeric in layer fed has beneficial effect in the change of Haugh unit during storage (Park et al., 2012).

While for the control group, albumen weight was observed to be greater than the $1 \%$ fenugreek concentration group (Panaite et al., 2015).

\section{Economic efficiency:}

As shown in Table (6), from the records of EE concerning egg production as influenced by the dietary supplementation with turmeric, fenugreek and plus of them together. The results indicated that, the highest significant values $(\mathrm{P}<0.05)$ of $\mathrm{EE}$ were observed for hen group ingested diet with mixture of TU plus FE (T6) compared to other treatments, followed by control treatment and $0.1 \%$ TU treatment (T2) which recorded 32.61, 32.08 and $29.84 \%$ respectively.

In contrast, fenugreek treatments scored lower EE than other treatments, especially with $0.2 \%$ FE which scored $11.20 \%$. Whilst, adding $0.2 \%$ FE plus $0.1 \%$ TU achieved significantly better EE compared 
turmeric, fenugreek, laying hens performance, egg quality.

to other groups. This means that, adding fenugreek to turmeric worked to enhance turmeric availability and coexistence, leading to the highest economic return.

Hassan et al. (2003) found that egg production increased economically with the addition of both germinated and nongerminated fenugreek seeds.

\section{GENERAL CONCLUSIONS}

Based on this study, it was concluded that adding turmeric to the old laying hens' diet improved egg weight and yolk \% and shell $\%$. The addition of the fenugreek also led to an improvement in egg weight higher than turmeric or control treatment.

Level $0.1 \%$ fenugreek was the best in egg weight and $0.2 \%$ was the best in the egg shell \%.

Adding turmeric and fenugreek together, led to an improvement in egg production, as well as egg quality, more than adding either one separately. Because addition of fenugreek with turmeric improved turmeric bioavailability. Curcumin has limited solubility in aqueous environments, such as the gastrointestinal tract and limited gastrointestinal absorption, rapid metabolism both in the intestines and the liver, chemical instability in alkaline medium, and inability to reach the blood in concentrations necessary to affect markers even at chronic doses of up to $12 \mathrm{~g}$ a day (Nguyen et al.,2017).

Recently, bioavailable form of curcumin, namely curcumagalactomannosides , formulated using fenugreek (Trigonella foenum-graecum) - derived soluble dietary fiber composed of galactose and mannose units (galactomannan). the relative absorption of curcumin from the novel fiber formulation was 20 times higher in animals when supplemented orally (Krishnakumar et al., 2012). Accordingly, we recommend adding turmeric and fenugreek together to laying hens' diet. 
H. M. M. Azouz

Table (1): Ingredients and calculated chemical analysis of the basal diet:

\begin{tabular}{|l|c|}
\hline Ingredients & \% \\
\hline Yellow corn & 64.00 \\
Soy bean meal (44 \%) & 22.50 \\
Corn gluten (60\%) & 1.58 \\
Wheat bran & 1.68 \\
Di-calcium phosphate & 1.40 \\
Limestone & 8.14 \\
Vit. \& Min. premix 1 & 0.30 \\
Sodium chloride & 0.30 \\
DL- Methionine (99\%) & 0.10 \\
Total & 100 \\
\hline Calculated Analysis 2 & \\
\hline Crude protein \% & 16.10 \\
ME ( Kcal / kg ) & 2730 \\
Crude fiber \% & 3.30 \\
Ether extract \% & 2.87 \\
Calcium (\%) & 3.43 \\
Av. Phosphorus (\%) & 0.39 \\
Methionine \% & 0.40 \\
Lysine \% & 0.84 \\
Methionine + Cystin \% & 0.68 \\
Price (LE/kg diet) & 5.02 \\
\hline
\end{tabular}

1-Each $3 \mathrm{~kg}$ of vitamins and Minerals premix contains 10 million IU vitamin A; 2 million IU Vit.D3;10 g vitamin E; 1 g Vit.K ${ }_{3} ; 1 \mathrm{~g}$ vitaminB1; $5 \mathrm{~g}$ vitamin $\mathrm{B} 2 ; 10 \mathrm{mg}$ vitamin $\mathrm{B} 12 ; 1.5 \mathrm{~g}$ vitamin B6; $30 \mathrm{~g}$ Niacin ; $10 \mathrm{~g}$ Pantothenic acid ;1g Folic acid; $50 \mathrm{mg}$ Biotin ; 300 g Choline; $50 \mathrm{~g}$ Zinc; $4 \mathrm{~g}$ Copper; $0.3 \mathrm{~g}$ Iodine ; $30 \mathrm{~g}$ Iron; $0.1 \mathrm{~g}$ Selenium; 60g Manganese ;0.1 g Cobalt; and carrier $\mathrm{CaCO}_{3}$ up to $3000 \mathrm{~g}$. 2- According to Feed Composition Tables for animal and poultry feedstuffs used in Egypt (2001). 
turmeric, fenugreek, laying hens performance, egg quality.

Table (2): Effect of dietary turmeric and fenugreek supplementation on laying performance of local Sinai hens:

\begin{tabular}{|c|c|c|c|c|c|c|c|c|}
\hline \multirow[b]{2}{*}{$\begin{array}{c}\text { Age } \\
\text { (wks.) }\end{array}$} & \multicolumn{6}{|c|}{ dietary turmeric (TU) and fenugreek (FE) \% } & \multirow[b]{2}{*}{$\begin{array}{c}\text { Pooled } \\
\text { SEM }\end{array}$} & \multirow[b]{2}{*}{ Sig. } \\
\hline & Control & 0.1TU & 0.1FE & $0.2 \mathrm{FE}$ & $\begin{array}{c}\text { 0.1TU } \\
+ \\
0.1 F E\end{array}$ & $\begin{array}{c}0.1 T U \\
+ \\
0.2 F E\end{array}$ & & \\
\hline \multicolumn{9}{|c|}{ Egg number/ hen } \\
\hline $59-62$ & $15.3^{\mathrm{a}}$ & $15.4^{\mathrm{a}}$ & $13.3^{\mathrm{ab}}$ & $13.5^{\mathrm{ab}}$ & $12.2^{\mathrm{b}}$ & $15.6^{\mathrm{a}}$ & 0.40 & 0.05 \\
\hline $63-66$ & 15.6 & 14.5 & 13.7 & 13.7 & 13.2 & 15.7 & 0.35 & NS \\
\hline $67-70$ & 14.6 & 14.8 & 13.7 & 14.3 & 14.8 & 15.3 & 0.34 & NS \\
\hline $71-74$ & $13.7^{\mathrm{a}}$ & $13.5^{\mathrm{a}}$ & $11.9^{\mathrm{a}}$ & $8.3^{\mathrm{b}}$ & $11.3^{\mathrm{a}}$ & $13.7^{\mathrm{a}}$ & 0.52 & 0.05 \\
\hline $59-74$ & 59.2 & 58.3 & 52.8 & 49.9 & 51.5 & 60.3 & 1.42 & NS \\
\hline \multicolumn{9}{|c|}{ Laying rate, \% } \\
\hline $59-62$ & $54.5^{\mathrm{a}}$ & $55.0^{\mathrm{a}}$ & $47.6^{\mathrm{b}}$ & $48.3^{\mathrm{ab}}$ & $43.6^{b}$ & $55.7^{\mathrm{a}}$ & 1.41 & 0.05 \\
\hline $63-66$ & 55.7 & 51.9 & 49.5 & 48.8 & 47.1 & 56.2 & 1.26 & NS \\
\hline $67-70$ & 52.1 & 52.9 & 49.0 & 51.2 & 52.9 & 54.8 & 1.22 & NS \\
\hline $71-74$ & $49.1^{\mathrm{a}}$ & $48.3^{\mathrm{a}}$ & $42.4^{\mathrm{a}}$ & $29.8^{b}$ & $40.2^{\mathrm{a}}$ & $49.9^{\mathrm{a}}$ & 1.85 & 0.05 \\
\hline $59-74$ & 52.9 & 52.0 & 47.1 & 44.5 & 46.0 & 53.9 & 1.36 & NS \\
\hline
\end{tabular}

${ }_{a, b . .}$ :means in the same row bearing different superscripts are significantly different $(\mathrm{P} \leq 0.05)$. NS: non significan.

Table (3): Effect of dietary turmeric and fenugreek supplementation on laying performance of local Sinai hens:

\begin{tabular}{|c|c|c|c|c|c|c|c|c|}
\hline \multirow[b]{2}{*}{$\begin{array}{c}\text { Age } \\
\text { (wks.) }\end{array}$} & \multicolumn{6}{|c|}{ dietary curcumin(TU) and fenugreek (FE) \% } & \multirow[b]{2}{*}{$\begin{array}{c}\text { Pooled } \\
\text { SEM }\end{array}$} & \multirow[b]{2}{*}{ Sig. } \\
\hline & Control & $0.1 \mathrm{TU}$ & 0.1FE & $0.2 F E$ & $\begin{array}{c}0.1 T U \\
+0.1 F E \\
\end{array}$ & $\begin{array}{c}0.1 T U \\
+0.2 F E \\
\end{array}$ & & \\
\hline \multicolumn{9}{|c|}{ Egg weight, $g$} \\
\hline $59-62$ & $52.7^{\mathrm{a}}$ & $51.1^{\mathrm{ab}}$ & $51.7^{\mathrm{ab}}$ & $50.5^{\mathrm{b}}$ & $52.6^{\mathrm{a}}$ & $50.1^{\mathrm{b}}$ & 0.31 & 0.05 \\
\hline $63-66$ & $51.0^{\mathrm{b}}$ & $51.2^{\mathrm{b}}$ & $51.9^{\mathrm{ab}}$ & $51.8^{\mathrm{ab}}$ & $52.8^{\mathrm{a}}$ & $51.1^{\mathrm{b}}$ & 0.22 & 0.05 \\
\hline $67-70$ & 51.1 & 51.4 & 51.4 & 51.6 & 51.9 & 51.5 & 0.14 & NS \\
\hline $71-74$ & $50.6^{\mathrm{b}}$ & $52.8^{\mathrm{ab}}$ & $52.9^{\mathrm{ab}}$ & $53.7^{\mathrm{a}}$ & $51.7^{\mathrm{ab}}$ & $52.3^{\mathrm{ab}}$ & 0.34 & 0.05 \\
\hline $59-74$ & $51.4^{\mathrm{b}}$ & $51.6^{\mathrm{ab}}$ & $52.0^{\mathrm{ab}}$ & $51.9^{\mathrm{ab}}$ & $52.3^{\mathrm{a}}$ & $51.2^{\mathrm{b}}$ & 0.12 & 0.05 \\
\hline \multicolumn{9}{|c|}{ Egg mass, g/ hen } \\
\hline $59-62$ & $805.7^{\mathrm{a}}$ & $787.5^{\mathrm{a}}$ & $689.2^{\mathrm{ab}}$ & $682.9^{\mathrm{ab}}$ & $641.5^{\mathrm{b}}$ & $781.9^{\mathrm{a}}$ & 20.24 & 0.05 \\
\hline $63-66$ & 794.8 & 743.6 & 720.0 & 708.5 & 697.6 & 804.1 & 17.37 & NS \\
\hline $67-70$ & 754.9 & 760.6 & 707.3 & 738.3 & 768.6 & 788.6 & 17.62 & NS \\
\hline $71-74$ & $595.1^{\mathrm{ab}}$ & $714.1^{\mathrm{a}}$ & $628.2^{\mathrm{ab}}$ & $446.3^{c}$ & $581.8^{\mathrm{b}}$ & $686.2^{\mathrm{ab}}$ & 25.26 & 0.05 \\
\hline $59-74$ & 3041.4 & 3005.8 & 2744.6 & 2576.0 & 2689.3 & 3060.8 & 70.79 & NS \\
\hline
\end{tabular}

a,b,c,: means in the same row bearing different superscripts are significantly different $(\mathrm{P} \leq 0.05)$.

NS: non significan. 
Table (4): Effect of dietary turmeric and fenugreek supplementation on feed intake and feed conversion of local Sinai hens

\begin{tabular}{|c|c|c|c|c|c|c|c|c|}
\hline \multirow[b]{2}{*}{$\begin{array}{c}\text { Age } \\
\text { (wks.) }\end{array}$} & \multicolumn{6}{|c|}{ dietary curcumin(TU) and fenugreek (FE) \% } & \multirow[b]{2}{*}{$\begin{array}{c}\text { Pooled } \\
\text { SEM }\end{array}$} & \multirow[b]{2}{*}{ Sig. } \\
\hline & $\begin{array}{c}\text { Contro } \\
l\end{array}$ & $0.1 T U$ & 0.1FE & 0.2FE & $\begin{array}{c}0.1 T U \\
+0.1 F E\end{array}$ & $\begin{array}{c}0.1 \mathrm{TU} \\
+0.2 \mathrm{FE}\end{array}$ & & \\
\hline \multicolumn{9}{|c|}{ Feed intake (g/hen/d) } \\
\hline $59-62$ & 104.8 & 104.1 & 104.1 & 104.2 & 104.8 & 106.1 & 0.56 & NS \\
\hline $63-66$ & $108.4^{\mathrm{a}}$ & $104.5^{\mathrm{ab}}$ & $102.6^{\mathrm{ab}}$ & $100.2^{\mathrm{ab}}$ & $98.4^{\mathrm{b}}$ & $102.7^{\mathrm{ab}}$ & 1.16 & 0.05 \\
\hline $67-70$ & $108.2^{\mathrm{b}}$ & $111.1^{\mathrm{ab}}$ & $111.4^{\mathrm{ab}}$ & $113.1^{\mathrm{ab}}$ & $115.5^{\mathrm{a}}$ & $109.5^{\mathrm{b}}$ & 0.78 & 0.05 \\
\hline $71-74$ & 108.7 & 109.8 & 111.2 & 111.6 & 110.1 & 111.2 & 0.98 & NS \\
\hline $59-74$ & 107.5 & 107.4 & 107.3 & 107.3 & 107.2 & 107.4 & 0.64 & NS \\
\hline \multicolumn{9}{|c|}{ Feed conversion $\mathrm{ratio}$ (g feed/g egg) } \\
\hline $59-62$ & $3.7^{\mathrm{c}}$ & $4.2^{\mathrm{bc}}$ & $4.3^{\mathrm{ab}}$ & $4.6^{\mathrm{a}}$ & $3.8^{\mathrm{c}}$ & $4.1^{b c}$ & 0.10 & 0.05 \\
\hline $63-66$ & 3.8 & 3.9 & 4.0 & 4.0 & 4.0 & 3.6 & 0.06 & NS \\
\hline $67-70$ & 4.1 & 4.1 & 4.5 & 4.3 & 4.2 & 3.9 & 0.10 & NS \\
\hline $71-74$ & $4.4^{\mathrm{bc}}$ & $4.3^{\mathrm{c}}$ & $5.0^{\mathrm{ab}}$ & $4.7^{\mathrm{bc}}$ & $5.3^{\mathrm{a}}$ & $4.6^{b c}$ & 0.23 & 0.05 \\
\hline $59-74$ & $4.0^{\mathrm{b}}$ & $4.0^{\mathrm{b}}$ & $4.4^{\mathrm{ab}}$ & $4.7^{\mathrm{a}}$ & $4.5^{\mathrm{ab}}$ & $3.9^{\mathrm{b}}$ & 0.09 & 0.05 \\
\hline
\end{tabular}

a,b,c,.. :means in the same row bearing different superscripts are significantly different $(\mathrm{P} \leq 0.05)$.

NS: non significan.

Table (5): Effect of dietary turmeric and fenugreek supplementation on egg quality traits of local Sinai hens

\begin{tabular}{|c|c|c|c|c|c|c|c|c|}
\hline \multirow[b]{2}{*}{ Traits } & \multicolumn{6}{|c|}{ dietary curcumin(TU) and fenugreek (FE)\% } & \multirow{2}{*}{$\begin{array}{c}\text { Pooled } \\
\text { SEM }\end{array}$} & \multirow[b]{2}{*}{ Sig. } \\
\hline & Control & 0.1TU & 0.1FE & $0.2 F E$ & $\begin{array}{r}\text { 0.1TA } \\
+0.1 F E \\
\end{array}$ & $\begin{array}{r}0.1 T U \\
+0.2 F E \\
\end{array}$ & & \\
\hline Sh. $\mathrm{I}^{1}$ & 0.83 & 0.80 & 0.78 & 0.78 & 0.78 & 0.81 & 0.01 & NS \\
\hline Yolk $I^{2}$ & 0.27 & 0.26 & 0.26 & 0.25 & 0.25 & 0.26 & 0.003 & NS \\
\hline Yolk \% & $32.7^{\mathrm{ab}}$ & $35.5^{\mathrm{a}}$ & $32.8^{\mathrm{ab}}$ & $31.5^{\mathrm{b}}$ & $33.7^{\mathrm{ab}}$ & $30.8^{\mathrm{b}}$ & 0.52 & 0.05 \\
\hline Alb. $\%^{3}$ & $54.0^{\mathrm{a}}$ & $50.2^{\mathrm{ab}}$ & $49.6^{\mathrm{ab}}$ & $49.3^{\mathrm{ab}}$ & $44.7^{\mathrm{b}}$ & $53.9^{\mathrm{a}}$ & 1.04 & 0.05 \\
\hline Shell \% & 13.1 & 13.3 & 13.6 & 13.0 & 13.4 & 12.7 & 0.24 & NS \\
\hline Sh. th. ${ }^{4}$ & 0.30 & 0.31 & 0.3 & 0.31 & 0.30 & 0.32 & 0.002 & NS \\
\hline H.U. ${ }^{5}$ & $87.9^{b c}$ & $82.1^{\mathrm{c}}$ & $88.7^{\mathrm{b}}$ & $89.5^{\mathrm{b}}$ & $93.2^{\mathrm{a}}$ & $91.4^{\mathrm{ab}}$ & 1.24 & 0.05 \\
\hline
\end{tabular}

$1=$ Shell index; 2 =Yolk index; 3 =Albumin \%; 4 =Shell thickness; 5 =Haugh units;

a,b,c,: :means in the same row bearing different superscripts are significantly different $(\mathrm{P} \leq 0.05)$.

NS :non significan 
turmeric, fenugreek, laying hens performance, egg quality.

Table (6): Effect of dietary turmeric and fenugreek supplementation on economic efficiency of local Sinai hens

\begin{tabular}{|c|c|c|c|c|c|c|c|c|}
\hline $\begin{array}{c}\text { Items } \\
\text { Treatments }\end{array}$ & $\begin{array}{c}\text { Total } \\
\text { feed } \\
\text { intake/ } \\
\text { hen } \\
\text { (kg) }\end{array}$ & $\begin{array}{c}\text { Feed } \\
\text { layer } \\
\text { cost/ } \\
\text { kg } \\
\left(\begin{array}{c}\text { EGP }) \\
1\end{array}\right.\end{array}$ & $\begin{array}{c}\text { Total } \\
\text { feed } \\
\text { intake } \\
\text { cost/ } \\
\text { hen } \\
\text { (EGP) }\end{array}$ & $\begin{array}{c}\text { Egg } \\
\text { number/ } \\
\text { hen }\end{array}$ & $\begin{array}{c}\text { Price } \\
\text { of } \\
\text { one } \\
\text { egg } \\
\text { (EGP) }\end{array}$ & $\begin{array}{c}\text { Total } \\
\text { return } \\
(\text { EGP) }\end{array}$ & $\begin{array}{c}\text { Net } \\
\text { return } \\
\text { (EGP) }\end{array}$ & $\begin{array}{l}\text { EEF } \\
(\%)^{2}\end{array}$ \\
\hline control & 12.04 & 5.02 & 60.42 & 59.20 & 1.35 & 79.92 & 19.50 & $32.08^{\mathrm{a}}$ \\
\hline $0.1 \mathrm{CU}$ & 12.00 & 5.04 & 60.51 & 58.27 & 1.35 & 78.66 & 18.15 & $29.84^{\mathrm{ab}}$ \\
\hline $0.1 \mathrm{FE}$ & 12.01 & 5.03 & 60.43 & 52.80 & 1.35 & 71.28 & 10.85 & $17.81^{\mathrm{abc}}$ \\
\hline $0.2 \mathrm{FE}$ & 12.00 & 5.04 & 60.48 & 49.87 & 1.35 & 67.32 & 6.84 & $11.20^{\mathrm{c}}$ \\
\hline $0.1 \mathrm{CU}+0.1 \mathrm{FE}$ & 12.00 & 5.06 & 60.65 & 51.47 & 1.35 & 69.48 & 8.83 & $14.40^{\mathrm{bc}}$ \\
\hline $\begin{array}{c}0.1 \mathrm{CU}+0.2 \mathrm{FE} \\
\text { SEM } \\
\text { Sig. }\end{array}$ & 11.98 & 5.07 & 60.69 & 59.80 & 1.35 & 80.73 & 20.04 & $\begin{array}{c}32.61^{\mathrm{a}} \\
1.70 \\
*\end{array}$ \\
\hline
\end{tabular}

${ }^{1} \mathrm{EGP}=$ Egyptian pound. According to price at the experimental time.

${ }^{2} \mathrm{EEF}(\%)=$ economic efficiency $(\%)=($ Net return LE $/$ Total feed cost LE $) \times 100$.

a,b,c :means in the same row bearing different superscripts are significantly different $(\mathrm{P} \leq 0.05)$.

NS: non significan

\section{REFERENCES}

Abaza, I. M., 2007. Effect of using fenugreek, chamomile and radish as feed additives on productive performance and digestibility coefficients of laying hens. Poult. Sci, 27, 199-218.

Abdalla A .A.; Mona, M., Ahmed; I .M., Abaza; O.M., Aly and E.Y., Hassan 2011. Effect of using some medicinal plants and their mixtures on productive and reproductive performance of gimmizah strain 2- egg production period. Egypt Poult. Sci 31:641-654.

Abdouli H, M. Haj-Ayed; S. Belhouane ; E. Hcini 2014. Effect of feeding hens with fenugreek seeds on laying performance, egg quality characteristics, serum and egg yolk cholesterol. J New Sci 3: 1-9.

Adil, S.; S. Qureshi, and R.A. Pattoo 2015. A Review on Positive Effects of Fenugreek as Feed Additive in Poultry
Production. Inter. J. of Poult. Sci. 14 (12): 664-669.

Alobaidy, R. N. 2012. Effect of fenugreek seeds and olive leaves ration supplementation on productive and physiological performance of laying breeder hen. M.Sc. thesis submitted to college of Agriculture and Forestry, University of Mosul, Iraq, pp:1-40.

Awadein, N. B. ; Z. E.Yahya and F. Z. Abd El-Ghany2010.Eeffect of

dietary supplementation with phytoestrogens sources before sexual maturity on productive performance of mandarah hens. Egypt. Poult. Sci. Vol (30) (III): (829-846).

Criste, R.D.; T. Panaite; A. Bercaru; I. Varzaru; M. Ropota; and G. M. Cornescu 2013. Study on the use of fenugreek in laying hens diets on egg quality, 19th European Symposium on Poultry Nutrition Potsdam, Germany. 
Curvelo, E. R.; A. Geraldo; L.M. Silva;

T.A. Santos; and V. Filho 2009.

Levels of inclusion of curcumin extract and turmeric in diets for semidried

hens and their effects on performance and egg yolk coloration. Proceedings of the II IFMG Science Technology Week.

Duncan, D.B1955.Multiple range and multiple F tests. Biometrics, 11:1-42.

Elangovan, A.V.; P.K. Tyagi; A.B, Mondal; P.K. Tyagi and Deo, C. 2011. Effect of dietary supplementation of certain herbal agents and cholesterol lowering drug on egg production performance and egg quality of Japanese quail layers. Indian Journal of Poultry Science. 46: 316-19.

Emadi, M. and H. Kermanshahi2007. Effect of varying levels of turmeric rhizome powder on someblood parameters of broiler chickens fed corn soybean meal based diets. Int. J. Poult.Sc.6 (5):345348.

Gu, H.; S.R. Shi; L.L. Chang; H.B. Tong; Z.Y. Wang; and J.M. Zou 2013. Safety evaluation of daidzein in laying hens: Part II. Effects on calciumrelated metabolism. Food and $\mathrm{Ch}$. Tox., 55, 689-692.

Gumus, H.; M. N. Oguz; K. E. Bugdayci; and F. K. Oguz 2018. Effects of sumac and turmeric as feed additives on performance, egg quality traits, and blood parameters of laying hens R. Bras. Zootec., 47:e20170114, 2018.

Hansen, K.; R. Kittok; G. Sarath; C. Toombs; N. Caceres; and M. Beck 2003. Estrogen receptor-alpha populations change with age in commercial laying hens. Poultry Science, 82, 1624-1629.
Her, C.; M.C.V. Julienne; and E. Roger 2018. Improvement of Curcumin Bioavailability for Medical Applications. Med Aromat Plants Journal. V: 7, Issue 6.

Johnson, A. L. 2000. Reproduction in the female. In G. C. Whittow (Ed.), Sturkie's avian physiology (5th ed., pp. 569-596). New York, NY: Academic Press.

Kanagaraju, P.;V.Omprakash; S. Rathnapraba; and G. Rajmanohar 2017.

Effect of turmeric (Curcuma Longa) on the egg production and biochemical parameters in layers. Indian Vet. J., April 2017, 94 (04) : 24 - 26.

Krishnakumar, I. M.; A. Ravi; D. Kumar; R. Kuttan ; B. Maliakel 2012.An enhanced bioavailable formulation of curcumin using fenugreek - derived soluble dietary fiber. Journal of Functional Foods 4 :348-357.

Laganá, C.; C.C. Pizzolante; E.S. Saldanha; and J.E. de Moraes 2011. Turmeric root and annato seed in second-cycle layer diets: performance and egg quality. Revista Brasileira de Ciência Avícola.; 13(3):171-6.

Makkar, H.P.S.; G. Tran; V. Heuzé; S.G. Reverdin; M. Lessire; F. Lebas; and P. Ankers 2015. Seaweeds for livestock diets: a review. Anim. Feed Sci. Technol. 1-24.

Malekizadeh, M.; M.M. Moeini; and S. Ghazi 2011. The effects of different levels of ginger (Zingiber officinale Rosc) and turmeric (Curcuma longa Linn) rhizomes powder on some blood metabolites and production performance characteristics of laying hens. J. of Agri. Sci. and Tech.; 14(1):127-34. 
turmeric, fenugreek, laying hens performance, egg quality.

Mazur, W. M.; J. A. Duke; and K. Wahala 1998. Iso-flavonoids and lignins in legumes: Nutritional and health aspects in human. Journal of Nutrition Biochemistry, 9, 193-200.

Morton, M. S.; G. Wilcox; M. L. Wahlqvist; and K. Griffiths 1994. Determination of lignans and isoflavonoids in human female plasma following dietary supplementation. J. of Endocri., 142, 251-259.

Moustafa, K. 2006. Effect of using commercial and natural growth promoters on the performance of commercial laying hens. Egyptian Poultry Science, 26, 941-965.

Nguyen, T.T.H.; J. Si; C. Kang; B. Chung; D. Chung; and D. Kim 2017. Facile preparation of water soluble curcuminoids extracted from turmeric (Curcuma longa L.) powder by using steviol glucosides. Food Chemistry 214: 366-373.

Omri, B.; R. Chalghoumi and H. Abdouli 2017. Study of the Effects of Dietary Supplementation of Linseed, Fenugreek Seeds and Tomato Pepper Mix on Laying Hen's Performances, Egg Yolk Lipids and Antioxidants Profiles and Lipid Oxidation Status. J. Anim. Sci. Livestock. Product. 1, 2.

Park, J.H.;Y.M. Kim and I.H. Kim 2018.Egg Production, Egg Quality, Blood Profiles, Cecal Microflora, and Excreta Noxious Gas Emissionin Laying Hens Fed with Fenugreek (Trigonella foenum-graecum L.) Seed Extract. J. Poult. Sci., 55: 47-53.

Park, S.S.; J.M. Kim; E.J. Kim; H.S. Kim; B.K. An; and C.W. Kang 2012. Effects of dietary turmeric powder on laying performance and egg qualities in laying hens. Korean Journal of Poultry Science.; 39(1):27-32.
Radwan, N. L.; R.A. Hassan; E.M.

Qota; and H.M. Fayek 2008. Effect

of natural antioxidant on oxidative stability of eggs and productive and reproductive performance of laying hens. International Journal of Poultry Science.; 7(2):134-50.

Rahardja, D. P.; M. R. Hakim; and V. S. Lestari 2015. Egg Production Performance of Old Laying Hen Fed Dietary Turmeric Powder. Inter. Sch. and Sci. Res. \& Inno. 9(7) 2015.

Rajesh, D.; K. Devvrat; and B. S. Tewatia 2018. Effect of turmeric powder on egg quality, gut morphology, ecology and on immune system of laying hen: A review. J. of Entomology and Zoology Studies; 6(3): 978-982

Riasi, A.; H. Kermanshahi; and A.H. Mahdavi 2012. Production performance, egg quality and some serum metabolites of older commercial laying hens fed different levels of turmeric rhizome (Curcuma longa) powder. Journal of Medicinal Plants Research.; 6 (11):2141-5.

Safaa, H. M., 2007. Effect of dietary garlic or fenugreek on cholesterol metabolism in laying hens - Egypt Poult. Sci. 27: 1207, 1221.

Saleh, A.A; Enas A. M. Ahmed and T.A. Ebeid 2019. The impact of phytoestrogen source supplementation on reproductive performance, plasma profile, yolk fatty acids and antioxidative status in aged laying hens. Reprod Dom Anim. , 54:846-854.

Saraswati, T.R; W. Manalu; D.R. Ekastutiand N. Kusumorini2013. The role of turmeric powder in lipid metabolism and its effect on quality. J. Indonesian Trop. Anim. Agric. 38(2):123-130. 
Seo, K.; M.S. Choi; U.J. jung ; H.J. Kim; J. Yeo; S.M. Jeon and M.K. Lee. 2008. Effect of curcumin supplementation on bloodglucose, plasma insulin, and glucose homeostasisrelated enzyme activities in diabeticdb/dbmice. Mol. Nutr. Food Res. 2008,52, 995-1004.

SPSS. 2008. SPSS User's Guide Statistics. Ver. 17. Copyright SPSS Inc., USA.

Williams, T.D.; C.E. Ames; and Y. Kiparissis 2005. Laying sequencespecific variation in yolk oestrogen levels, and relationship to plasma oestrogen in female zebra finches (Taeniopygia guttata). Proceedings of the Royal Society of London. Series B, Biological Sciences, 272,173-177.

Williams, C. A. 2019. The effect of Nutrifen ${ }^{\circledR}$ and Nutrifen Plus ${ }^{\circledR}$ in the diet of Hy-Line layers on production, egg quality and egg shelf life. Master of Science, Faculty of Agri Sciences, Stellenbosch University. Stellenbosch University. https://scholar.sun.ac.zYassein,

S. A.; G. M. El-Mallah; and M. A. Sawsan 2015. Response of laying hens to dietary flaxseed levels on performance, egg quality criteria, fatty acid composition of egg and some blood parameters. Inter. J.of Res. Studies in Biosciences, 10, 27-34.

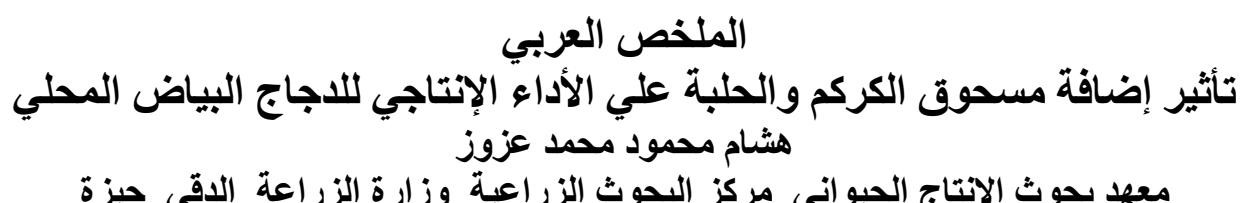

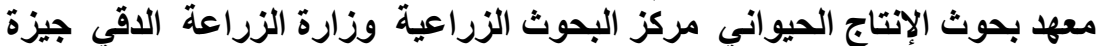

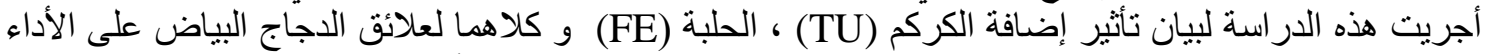

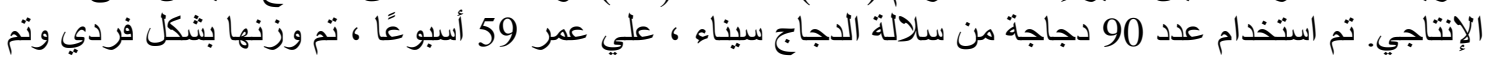

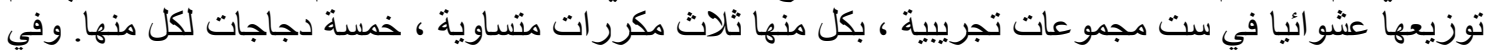

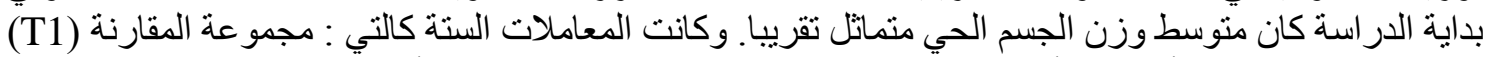

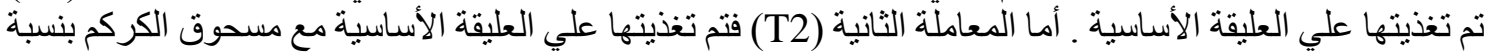

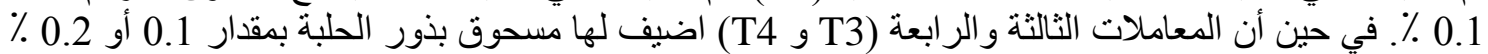

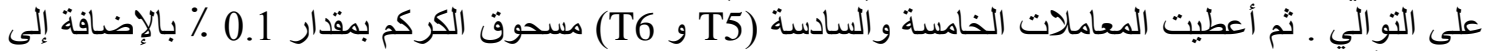

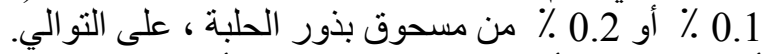

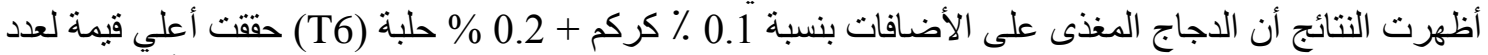

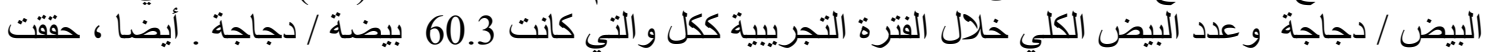

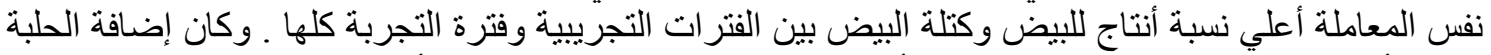

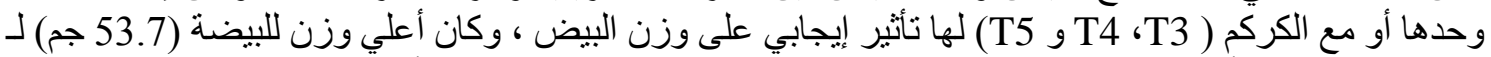

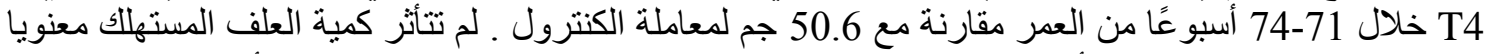

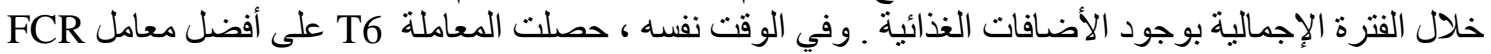

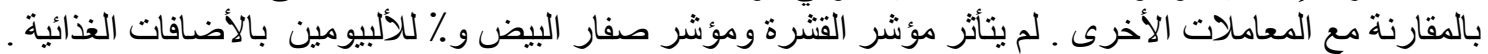

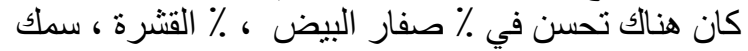

ث8= القشرة ووحدات Haugh بسبب الإضافات الغذائية (الكركم ، الحلبة أو كلبهما معا) إلي علائق الدجاج البياض .

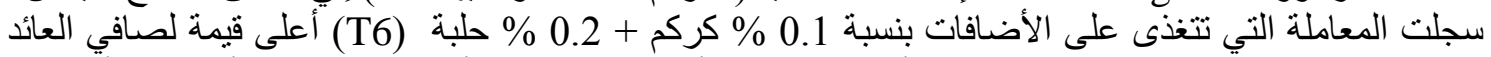

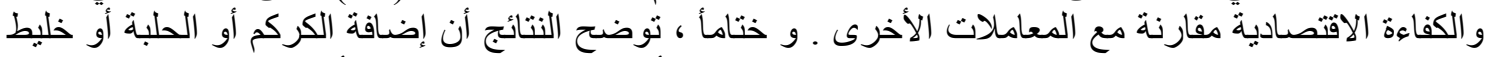

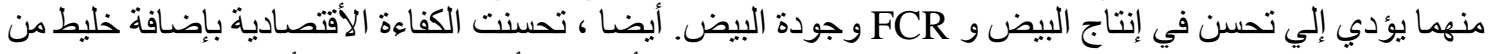
الإضافات الغذائية إلى علائق دجاج سيناء المحلي خلال مر احل الأنتاج المتأخرة ، 59 - 74 أسبوع من العمر. 
turmeric, fenugreek, laying hens performance, egg quality. 